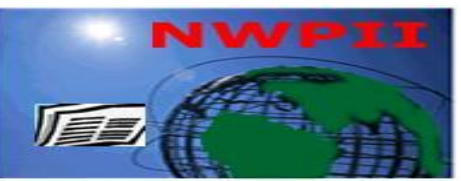

American Journal of Biomedical Sciences

ISSN: 1937-9080

nwpii.com/ajbms

\title{
The Kinin System: Present and Future Pharmacological Targets
}

\author{
J. N. Sharma* and G. J. AL-Sherif
}

Department of Applied Therapeutics, Faculty of Pharmacy, Health Sciences Centre, Kuwait University, Kuwait

*Corresponding author

J. N. Sharma

Department of Applied Therapeutics

Faculty of Pharmacy

Health Sciences Centre, Kuwait University

P.O.Box 24923

Safat, 13110, Kuwait

Tel: +965-498-6530

Fax: +965-534-2807

Email: j.n.sharma@hsc.edu.kw

Received: 14 December 2010; | Revised: 10 March 2011; | Accepted: 18 March 2011

\begin{abstract}
Kallikrein kinin system (KKS) is a complex system produced in various organs. This system includes kininogen (precursor for kinin), kallikreins and the pharmacologically active bradykinin (BK) which is considered either proinflammatory or cardioprotective. It's a proinflammatory polypeptide that is involved in many pathological conditions and can cause pain, inflammation, increased vascular permeability, vasodilation, contraction of various smooth muscle as well as cell proliferation. On the other hand, it has been shown that BK has cardioprotective effects as all components of KKS are located in the cardiac muscles. Numerous observations obtained show that decreased activity of this system may lead to cardiovascular diseases such as hypertension, cardiac failure and myocardial infarction. BK acts on two receptors, $B_{1}$ and $B_{2}$ receptors which are linked physiologically through their natural stimuli and their common participation in a variety of inflammatory responses. Recently, numerous BK antagonists have been developed in order to treat several diseases which are due to excessive BK formation. Although BK has many beneficial effects, some undesirable effects have been recognized that can be reversed with BK antagonists. In addition, products of this system have multiple interactions with other important metabolic pathways such as the renin-angiotensin system.
\end{abstract}

Keywords: Bradykinin, Bradykinin agonists, Bradykinin antagonists, Kallikrein-kinin system, Inflammation, Cardioprotection. 


\section{Introduction to the Kallikrein Kinin System}

The kallikrein kinin system is complex with several bioactive peptides that are formed in vascular smooth muscles as well as in the heart. The main constituents of this system are enzymes such as kallikreins, protein precursors which are kininogens and the potent vasoactive peptide kinin.

Kallikreins are serine proteases found in glandular cell, neutrophils and biological fluids. They are divided into two groups: tissue kallikrein and plasma kallikrein. Both differ in molecular weight, amino acid composition, type of kinin released and the functions.

Kinin is the vasoactive component in this system which is released through the actions of kallikreins on kininogens. In humans, kinin refers to the bradykinin (BK), kallidinin and carboxy terminal des-Arg metabolites. Also, T-kinins(IleSer-BK) and Met-T-kinin have been found only in rats. Kinins mediate a variety of physiological actions related to cardiovascular homeostasis, inflammatory, algesic responses and pain transmitted mechanisms ${ }^{1}$. These actions are promoted by activation of at least two receptor subtypes which are $\mathrm{B}_{1}$ and $\mathrm{B}_{2}$ receptors. Also, kinins activate endothelial cells resulting in vasodilation, increased vascular permeability, production of NO (nitric oxide) and releasing tissue type plasminogen activator (t-PA).

Kinins, bradykinin and lysylbradykinin are important mediators of inflammatory responses. They are librated from precursor molecule kininogen by various proteases known as kininogenases. There are three types of kininogens; high (HMW) and low (LMW) molecular weight kininogen and T-kininogen. These molecules are synthesized by hepatocytes and released into plasma. They play a role in releasing kinin.

Bradykinin (BK) and kallidin or lysylbradykinin are two peptides referred as kinins. BK is a nonapeptide usually found in all secretions of the body such as urine, saliva and sweat. Also it is found in several tissues such as heart, vasculature, blood, kidney, colon and liver ${ }^{2}$. $\mathrm{BK}$ is produced by plasma kallikrein and also it can be produced from kallidin by several aminopeptidases through cleavage of amino terminal lysine. On the other hand, kallidin is a decapeptide found in the heart, urine and circulation ${ }^{2}$. Kallidin is produced by tissue kallikrein and it is rapidly converted to BK by the enzyme aminopeptidase $\mathrm{N}$.

In addition to BK and kallidin there are two other kinin fragments which are:

des-arg-BK or BK-(1-8), and des-arg-KD or KD(1-9). They can interact with kinin receptors and function as agonists for type1 bradykinin receptors. They are stimulators of type1 BK receptors. Moreover, BK-(1-7) is an inactive degradation product, whereas $\mathrm{BK}-(1-5)$ is involved in the coagulation system.

In this paper we discuss the formation and pathophysiological roles of kinin system, define the proinflammatory and the cardioprotective effects of kinin system, outline the involvement of the kinin system in the regulation of the renin system, discuss the future prospects of kinins related therapy for pathological conditions and describe the undesired effects of kinins.

\section{Formation of bradykinin}

BK is a vasoactive peptide that is formed during inflammatory response from either HMW or LMW kininogen by action of enzyme called kallikreins. Three proteins are involved in BK formation; Hageman factor, prekallikrein and HMW kininogen. Plasma prekallikrein circulates in a complex form with HMW kininogen. This complex together with Hageman factor binds to negatively charged surface including basement membrane components and proteoglycans such as heparin. Once they are exposed by tissue damage, prekallikrein is rapidly converted to plasma kallikrein by the enzyme prolylcarboxypeptidase. Kallikreins are the enzymes that break down kininogen (the precursors of kinin). There are two forms of kallikreins; plasma kallikrein which converts HMW kininogen to $\mathrm{BK}$ and tissue kallikrein which converts LMW kininogen to lysyl-bradykinin (kallidin) which is rapidly converted to BK by the enzyme aminopeptidase $\mathrm{N}$ as shown in the figure 1 . 


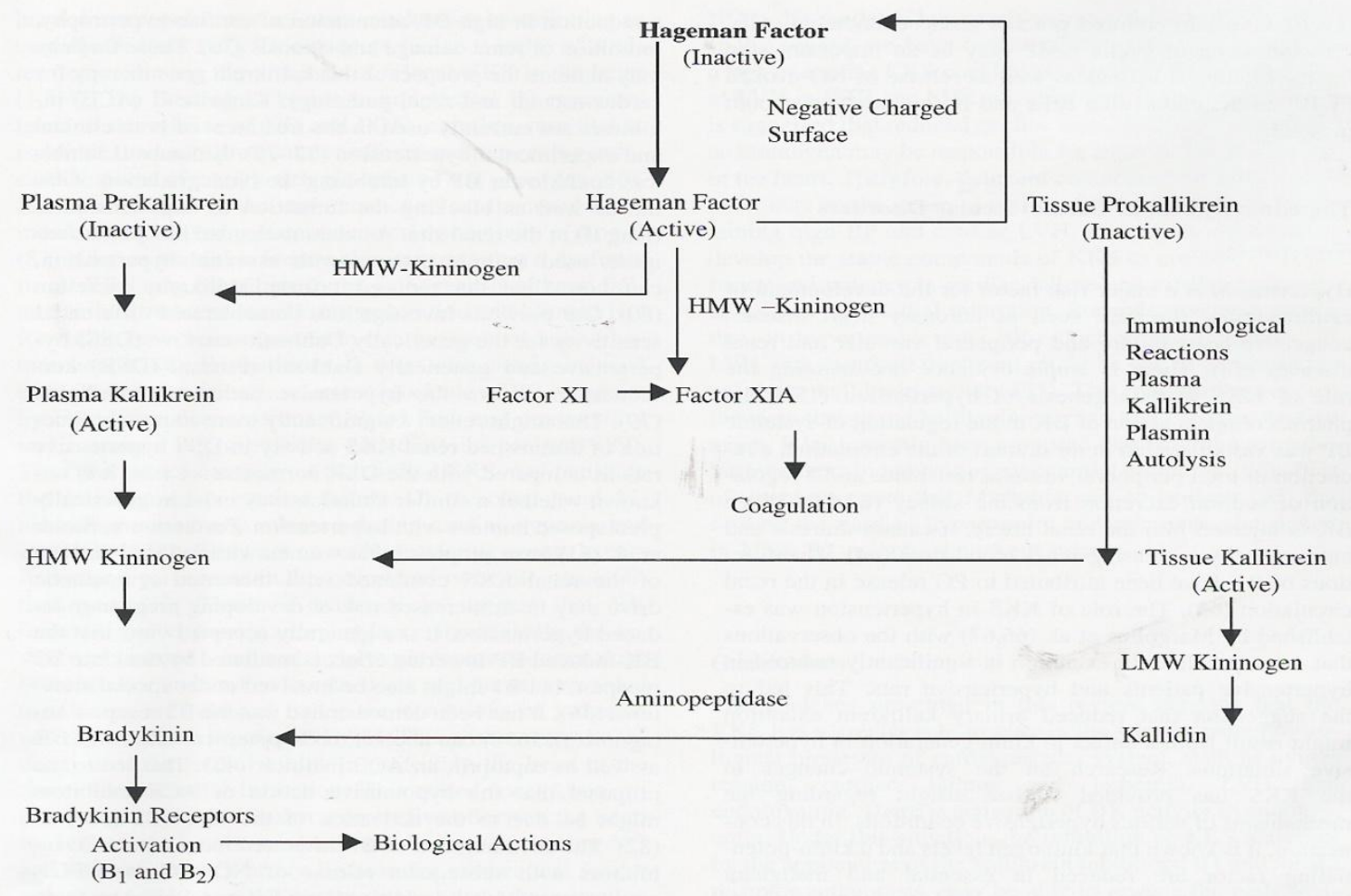

Figure 1. Mode of the kinin formation.

\section{Degradation of bradykinin}

Degradation of BK peptides are done by enzymes called kininases. Kininases cleave BK at either their aminoterminal or carboxyterminal end. Enzymes that cleave at aminoterminal are: aminopeptidase M (APM), which can degrade kallidin into $\mathrm{BK}^{3}$, and aminopeptidase $\mathrm{P}$ (APP), which cleaves the first amino acid of $\mathrm{BK}$ to give BK-(2-9).

On the other hand, there are four major enzymes responsible for carboxyterminal degradation of $\mathrm{BK}$, which are: angiotensin converting enzyme ACE, carboxypeptidase $\mathrm{N}$ and $\mathrm{M}$ (CPN, CPM) and neutral endopeptidase NEP. These kininase can be divided into two groups on the bases of their enzymology. The first group is kininase I which includes CPN and CPM, and the second group is kininase II which includes ACE and NEP. Enzymes of kininase type I cleave the carboxyterminal arginine from either $\mathrm{BK}$ or kallidin to give des-Arg9-BK or des-Arg10-KD, while enzymes of kininase type II cleave the dipeptide Phe8-Arg9 from both BK and kallidin to give BK-(1-7) and KD-(1-8). These are further cleaved by ACE to give BK-(1-5) and KD-(1-6).

\section{Receptors for bradykinin}

There are two subtypes of $\mathrm{BK}$ receptors; $\mathrm{B}_{1}$ and $\mathrm{B}_{2}$ receptors according to IUPHAR classification. These two receptors have similar structures with seven transmembrane domain coupled to G-protein. Also, $\mathrm{B}_{3}$ and $\mathrm{B}_{4}$ receptors have been proposed as additional receptors 1,2 .

$\mathrm{B}_{1}$ and $\mathrm{B}_{2}$ receptors are structurally similar; however there are many differences in their functions in living organisms. To begin with, $\mathrm{B}_{1}$ receptors are expressed at a very low level in healthy tissue and they are inducible following tissue injuries and by endogenous factors (endotoxins, cytokines, growth factors), while $\mathrm{B}_{2}$ receptors are predominant and constitutively expressed in vascular, non vascular smooth muscles and the heart. In addition, $\mathrm{B}_{1}$ receptors have no desensitization and internalization ${ }^{4}$, where as $B_{2}$ receptors desensitization is due to negative cooperativity, which is a phenomenon 
observed with G-protein coupled receptors. Both receptors have been cloned and their structures elucidated. Moreover, signal transduction mechanisms are quite similar for $B_{1}$ and $B_{2}$ receptors, since they are coupled to G-proteins so they require calcium for signaling 5 .

\section{Physiological effects of $B_{1}$ receptors}

$\mathrm{BK} \mathrm{B}_{1}$ receptors have role in different systems. First of all, in the circulation $\mathrm{B}_{1}$ receptors stimulation can cause vasodilatation in the vessels. Also, in cardiovascular system $\mathrm{B}_{1}$ receptors have been shown to precondition the heart against ischemic events and protect the heart from arrhythmias. In addition, $\mathrm{B}_{1}$ receptors are involved in renal functions by affecting both natriuresis and glomerular filtration. Also, they involve in the pathogenesis of diabetes. In inflammation, $\mathrm{B}_{1}$ receptors involve in leucocytes recruitment and in the initiation of inflammatory responses as well as in the physiology of pain. Finally, it has been shown that $B_{1}$ receptors are mitogenic in fibrotic tissues ${ }^{6,7}$.

\section{Physiological effects of $B_{2}$ receptors}

$\mathrm{B}_{2}$ receptors produce different effects on a number of tissues. In vasculature, $\mathrm{B}_{2}$ receptors signaling can lead to vasoconstriction or vasodilatation, and it can cause either stimulation or inhibition of growth in parenchymal tissues. In cardiovascular system, $\mathrm{B}_{2}$ receptors have been shown to be antiarrhythmic in the heart and antithrombotic in the vasculature. Also, $\mathrm{B}_{2}$ receptors reduce infarct size and they precondition the heart against ischemic events. Moreover, these receptors improve the myocardial demand of oxygen in heart failure by attenuating the endothelial dysfunction.

In addition, $\mathrm{B}_{2}$ receptors affect other systems. In diabetes, they affect glucose metabolism either directly or by interaction with insulin. Also, BK and its receptors have a role in alimentary tract. They affect smooth muscle cells of duodenum, ileum and cecum causing either relaxation or contraction. Moreover, $\mathrm{B}_{2}$ receptors have a role in the pathogenesis of asthma as they cause chloride secretion and bronchoconstriction. $\mathrm{B}_{2}$ receptors affect also the functions of reproductive organs and bladder by inducing smooth muscle contraction in vas deferens, uterus and bladder. Finally, $\mathrm{B}_{2}$ receptors involve in the physiology and pathophysiology of pain, inflammation and hyperalgesia.

\section{Pathophysiological role of bradykinin}

Pain and neurology: Pain producing effect of $\mathrm{BK}$ is due to stimulation of afferent nerve terminals. This is caused by the presence of $B_{2}$ receptors on neural elements as in nonmylinated nerve terminals, sensory ganglia and dorsal layer of the spinal cord, thus BK is both algesic and hyperalgesic ${ }^{8}$. Although these effects are mediated mainly by $\mathrm{B}_{2}$ receptors, $\mathrm{B}_{1}$ receptors are also involved in the process of pain perception since $\mathrm{B}_{1}$ receptor agonist [des $\mathrm{Arg}^{9} \mathrm{BK}$ ] exacerbate the pain. BK induced algesia and hyperalgesia have been shown using a number of models such as: BK evoked pain in human blister base, and in the BK elicited vascular pain and cutaneous hyperalgesia in rat. Moreover, BK has been reported to cause depolarization in nerve fiber by the activation of sodium channels and it is also involved in the chemokine induced hyperalgesia by activation of both $B_{1}$ and $B_{2}$ receptors. In addition, pain related to local inflammation of small intestine or bladder is mediated by endogenous BK through a viscero visceral hyper reflexia. This hyper reflexia can be inhibited by $\mathrm{BK}$ receptor antagonist. Also, expression of $\mathrm{B}_{1}$ receptors has been shown in inflammatory bowel diseases such as ulcerative colitis and Crohn's disease ${ }^{9}$.

Allergy: BK is involved in the pathogenesis of allergic asthma and bronchitis. Earlier reports indicated that injecting skin with BK may cause Lewis's triple response which is similar to that caused by histamine. BK either released with the air way tissue or derived from blood stream can stimulate sensory nerves to release tachykinin. Tachykinins cause bronchoconstriction and plasma exudation during the anaphylactic response. This involvement of tachykinin in BK induced plasma leakage in the airway constitutes neurogenic aspect of asthma ${ }^{10}$.

\footnotetext{
(C) 2011 by NWPII. All rights reserved. 
Rhinitis: There is a lot of evidence showing that $\mathrm{BK}$ is involved in the symptoms of different types of rhinitis. Specific binding to $\mathrm{B}_{2}$ receptors are found in the nasal turbinate of guinea pigs and man. Also by using a sensitive lavage method elevated BK levels have been detected in the nasal cavity of man. The receptors involved in these effects are mainly $B_{2}$ receptors type; since selective $\mathrm{B}_{1}$ receptor agonist (des Arg9 BK) does not produce such effects. Moreover, the effects of BK on nasal cavity and lower airway are mediated partly by platelet activating factor (PAF).

Fever: Fever is a reaction to sepsis and inflammation in which BK and prostaglandins (PGs) may play a role. Intravenous administration of BK causes a febrile reaction in the rat and it is inhibited by i.c.v. injection of HOE 140 which is $\mathrm{B}_{2}$ receptor antagonist and also by $\left[\mathrm{Leu}^{8}\right]$ des $\mathrm{Arg}^{9}$ BK which is $B_{1}$ receptor antagonist ${ }^{10}$. These data reported that endogenous $\mathrm{BK}$ in central nervous system has a role in thermoregulation process.

\section{GI diseases}

BK receptors are involved in many gastrointestinal diseases. First, dumping syndrome which results as a complication of gastric surgery is characterized by flushing and hypotension with excessive release of BK and tryptophan 5hydroxylase from the gut. Moreover, carcinoid syndrome results in excessive production of kallikrein and tryptophan 5-hydroxylase in enterochromaffin cells caused by intestinal tumors and hepatic metastases.

In addition, the release of prostaglandins by $\mathrm{BK}$ increases the secretion of chloride and water which link BK to diarrhea in gastroenteritis. Also, prostaglandins released by $\mathrm{BK}$ have a role in human adenocarcinoma. Both $\mathrm{B}_{1}$ and $\mathrm{B}_{2}$ receptors are involved in this pathological process. $\mathrm{BK}$ is also involved in the chronic inflammation of colonic mucosa and ulcerative colitis ${ }^{9}$.

\section{Proinflammatory effects of bradykinin}

BK may play an important role in the development of inflammatory process. It has been reported that this peptide caused signs of inflammation (redness, local heat, swelling and pain) when injected into animal tissues. This inflammatory response to BK seems to be due to $B_{2}$ receptor activation which causes vasodilatation due to production of $\mathrm{NO}$ and PGI and also increased permeability of vascular endothelium to fluid and plasma proteins that result in edema. It is well known that $\mathrm{B}_{2}$ receptors are mainly responsible for development of signs of inflammation, thus $\mathrm{B}_{2}$ receptor antagonist prevent specific inflammatory responses in specific models. Examples are: tissue swelling and systemic signs of inflammation in peptidoglycan induced arthritis in the Lewis rat and plasma extravasations in the Arthus reaction ${ }^{11,12}$. Also, $\mathrm{B}_{2}$ receptor antagonists play a role in some forms of vasogenic edema such as: brain edema following head trauma or stroke and hereditary angiodema. On the other hand there are experimental evidences for the involvement of the up regulation of $\mathrm{B}_{1}$ receptors in chronic inflammatory processes including periodontitis, rheumatoid arthritis, osteomyelitis, chronic cystitis, and also $B_{1}$ receptors of $B K$ are involved in the neurogenic inflammatory process. The reports have shown that tachykinin mediated capsaicin evoked edema in the mouse ear is inhibited by antagonist of $B_{1}$ receptor more than $\mathrm{B}_{2}$ receptor. This suggests the existence of $\mathrm{B}_{1}$ receptors on neurokinin nerves which modulate the neurogenic inflammation in these species. In addition, BK is responsible for many effects in leukocytes including: the release of other inflammatory mediators like cytokines, prostaglandins, leukotriens and reactive oxygen species. Also, an up regulation of BK receptors on neutrophils and macrophages appear to be involved in increasing the sensitivity of these cells to $\mathrm{BK}$ at the site of inflammation.

Moreover, elevated BK levels are detected in the plasma of asthmatics. Increasing levels of BK has been found in symptomatic asthmatic subjects, but not in asymptomatic subjects. BK has direct and indirect airway actions which include neurogenic inflammation by stimulation of sensory nerve fibers, arteriolar dilatation, vasoconstriction and plasma extravasation leading to mucosal edema, contraction of smooth muscles contributing to bronchoconstriction and release of inflammatory mediators such as cytokine ${ }^{10,13}$. In 
addition, $\mathrm{BK}$ acting through $\mathrm{B}_{1}$ and $\mathrm{B}_{2}$ receptors may stimulate proliferation of number of normal and neoplastic cell types through increasing oxygenation and nutrition of the proliferating tissue, there by facilitate cell growth as in A431 carcinoma cells and small cell lung carcinoma cells. Also, BK may have mitogenic roles in a range of clinical conditions associated with cellular proliferation including (1) psoriasis which is characterized by excessive keratinocyte proliferation that produce hyperplasic skin plaque, (2) in kidney, BK may contribute to the mesangial cell proliferation which may lead to glomerulonephritis, (3) BK can stimulate vascular smooth muscle proliferation and it may contribute to the medial and intimal hyperplasia of hypertension and atherosclerosis 13. Similarly, mitogenic action of BK may be involved in the endometrial proliferation during menstrual cycle and in lymphocyte proliferation in addition to enhancement of the immune response which demonstrate the role of $\mathrm{BK}$ in multiple sclerosis.

\section{Cardioprotective effects of bradykinin}

BK has multiple effects on cardiovascular system. These effects are produced through vasodilatation and plasma extravasation properties which lead to inflammation ${ }^{14}$. Vasodilatation is mainly mediated by B2 receptor; however under inflammatory conditions $\mathrm{B}_{1}$ receptor upregulation mediates BK induced vasodilatation and hypotension. BK is a potent vasodilator; it acts through stimulation of endothelial cell causing release of secondary mediators which affect the vascular smooth muscle. These mediators are nitric oxide (NO) and prostaglandin $\mathrm{I}_{2}\left(\mathrm{PGI}_{2}\right)$. $\mathrm{NO}$ is derived from L- arginine by endothelial nitric oxide synthase and it diffuses from endothelium to smooth muscle where it activates guanylate cyclase. The other secondary mediator released by $\mathrm{BK}$ is prostaglandin $\mathrm{I}_{2}$ (prostacyclin). Its formation occurs in many cell types through cytosolic $\mathrm{ca}^{2+}$ sensitive isoform of phospholipase $\mathrm{A}_{2}$, and it stimulates cyclic AMP production in the smooth muscle cell. Also, other mechanism of endothelium dependent vasorelaxation is suspected such as: the activation of a number of NO independent ion channels located in the smooth muscle cells ${ }^{15}$. These physiological effects of BK are useful in the treatment of hypertension and ischemic disorders in addition to maintaining renal function. Many studies were done on knockout mice that lack $\mathrm{B}_{2}$ receptors and laboratories had investigated enhancement effect of endogenous, exogenous arginine vasopressin and exogenous angiotensin II ${ }^{16}$, distorted renal development in the fetus with abnormal distal nephrons, reduced glomerular capillary surface area, decreased renin and cyclooxygenase COX 2 expression in the kidney ${ }^{17}$, insulin resistance state and increased renal fibrosis in response to unilateral urethral obstruction ${ }^{18}$. All these findings support the protective role of kallikrein kinin system in cardiovascular and renal disorders.

In addition, BK elevates cardiac out put and causes coronary dilatation, which is beneficial during myocardial infarction and post infarction period. The coronary dilatation induced by $\mathrm{BK}$ is mediated by the activation of $\mathrm{B}_{2}$ receptors; since $\mathrm{B}_{2}$ receptor antagonist HOE140 inhibit the effects on the coronary arteries. Also, both $\mathrm{NO}$ and $\mathrm{PGI}_{2}$ are involved in $\mathrm{BK}$ induced coronary dilatation, in contrast $\mathrm{B}_{1}$ receptor agonist (des $\mathrm{Arg}^{9} \mathrm{BK}$ ) doesn't affect coronary blood flow.

Moreover, $\mathrm{B}_{2}$ receptors are involved in the regulatory effect of nitric oxide on myocardial oxygen consumption. Recently, experimental evidences have suggested that G-protein mediated "cross-talk" mechanism between $\mathrm{B}_{2}$ receptors, NO synthase enzyme and angiotensin AT1 receptors may play an important role in cardioprotective effects of BK. Also, another interesting implication of $\mathrm{BK}$ is the ischemic preconditioning which is believed to strengthen their cardioprotective properties. It has been shown that $\mathrm{B}_{2}$ receptor activation is involved in the experimental ischemic preconditioning in rabbits, guinea pig and rat hearts. Moreover, BK exhibited pleiotropic effects by inhibiting apoptosis, inflammation, hypertrophy, fibrosis and promoting angiogenesis in the heart.

\section{Involvement of the kinin system in the regulation of renin system}

The first recognized important link between these two systems was angiotensin-converting 
enzyme (ACE). This enzyme has the bifunctional activities of being one of the degrading peptidases (kininase II) of BK and converting the inactive 10amino acid angiotensin I to the biologically active 8-amino acid angiotensin II which induces local vasoconstriction and increases blood pressure. Recently, a homologue of ACE has been recognized which is ACE $2{ }^{19}$. ACE 2 is carboxypeptidase mainly located in the heart, kidney and testis. It degrades angiotensin I to angiotensin (1-9) by removing the $\mathrm{COOH}$ terminal lysine. Angiotensin (1-9) enhances arachidonic acid release by $\mathrm{BK}$ and it resensitizes the $\mathrm{BK} \mathrm{B}_{2}$ receptors. Moreover the effects of $\mathrm{ACE}$ on $\mathrm{BK}$ metabolism have been shown by the influence of ACE inhibitors (ACE I) on a number of biologic processes. ACE inhibitors result in $25 \%$ reduction in death from cardiovascular disease, $20 \%$ reduction in myocardial infarction, $30 \%$ reduction of stroke, $22 \%$ reduction in heart failure and $16 \%$ reduction in complications of diabetes ${ }^{20}$. Furthermore, BK elevation after ACE inhibitor treatment improves left ventricular diastolic dysfunction, improve insulin resistance and reduce the progression of different fibrotic renal diseases in animal models.

In addition, it has been shown that there are interactions between angiotensin (1-7) and BK. Angiotensin (1-7) is produced by ACE 2 or by degradation of angiotensin II through prolylcarboxypeptidase. Also, neprilysin and thimet oligopeptidase can produce angiotensin (17) from the breakdown of angiotensin I. All these enzymes are involved in BK metabolism. There are interactions between angiotensin (1-7) and kallikrein kinin system that have been studied in kidney which are: potentiation of BK by angiotensin (1-7), mediation of vascular activity of angiotensin (1-7) by $\mathrm{BK}$, potentiation of the hypotensive and vasodilatory effects of $\mathrm{BK}$ in normotensive or hypertensive rat and dilating coronary artery through BK and nitric oxide. Moreover, angiotensin (1-7) influences BK by inhibiting $\mathrm{ACE}$, stimulating $\mathrm{BK} \mathrm{B}_{2}$ receptors and stimulating its own receptors that may interact with $\mathrm{BK}$ receptors.

Furthermore, interactions between plasma and tissue kallikrein with renin angiotensin system have been reported. Both plasma and tissue kallikrein are activators of prorenin. Plasma kallikrein is essential enzyme for prorenin activation after factor XII activation of plasma. This activation can occur at neutral pH. However, tissue kallikrein has been reported as prorenin converting enzyme at $\mathrm{pH}$ 8.2. Also, mouse tissue kallikrein mk1, mk9, mk13 and mk22 were shown to be prorenin activator in addition to human tissue kallikrein hk $1^{21}$.

Recent studies indicate that the enzyme prolylcarboxypeptidase which is an angiotensin II inactivating enzyme is also a prekallikrein activator. The ability of prolylcarboxypeptidase to act in kallikrein kinin system and renin angiotensin system indicates a novel interaction between them. Prolylcarboxypeptidase is a serine protease enzyme which is the first endothelial cell prekallikrein activator that has been identified. Its actions are: formation of angiotensin (1-7), BK release, vasodilatation and lowering blood pressure.

Furthermore, angiotensin II receptor have been implicated in the cross talk between the renin angiotensin system and the kallikrein kinin system. The finding first recognizes this evidence that renin angiotensin system stimulates renal BK production and cGMP formation through angiotensin II receptors 2 (AT2). This shows that stimulation of AT2 receptor results in releasing BK and nitric oxide. The ability of angiotensin II to directly stimulate renal BK production was shown in conscious rats and this effect is blocked by $\mathrm{AT}_{2}$ receptor antagonist not by $\mathrm{AT}_{1}$ receptor antagonist. Moreover, in rat $\mathrm{AT}_{2}$ receptor stimulation induced a systemic vasodilator response mediated by $\mathrm{BK}$ and nitric oxide, which counterbalance the vasoconstrictor action of angiotensin II at the $\mathrm{AT}_{1}$ receptor. This suggests that $\mathrm{AT}_{1}$ receptor blockage potentiates the cardiovascular effects of ACE inhibitors in the heart and kidney.

Another potential interaction between the renin angiotensin system and the kallikrein kinin system may be the modulation of the renin angiotensin system by BK peptide level. It has been shown that $\mathrm{BK}$ administration increases renin secretion. This effect is mediated by increased nitric oxide formation and administration. Also, it is reported 
Ligands application studies

\begin{tabular}{|c|c|c|}
\hline R-838(Sar-[D-Phe ${ }^{8}$ des- $\frac{\text { Agonists }}{\left.\text { Arg }^{9}-\mathrm{BK}\right)}$ & $\begin{array}{l}\text { - Metabolically stable } \\
\text { - High affinity and selectivity } \\
\quad-\text { Hypertension } \\
\text { - Stimulation of vascular formation } \\
\text { following ischemia }\end{array}$ & $\begin{array}{l}\text { - Rabbit } \\
\text { - rodent }\end{array}$ \\
\hline$\left[\right.$ Leu $\left.^{8}\right] \frac{\text { Antagonists }}{\text { des-Arg }}$ & $\begin{array}{r}\text { - Pain } \\
\text { - Ischemic vascular disease }\end{array}$ & $\begin{array}{r}\text { - Rat } \\
\text { - Mice }\end{array}$ \\
\hline Lys-[Leu $\left.{ }^{8}\right]$ des-Arg ${ }^{9}-\mathrm{Bk}$ & - Optimal $\mathrm{B}_{1}$ receptor antagonist & - Human $B_{1}$ receptor antagonist \\
\hline Ac-Lys-[MeAla ${ }^{6}$, Leu $\left.^{8}\right]$ des-Arg ${ }^{9}-B K$ & $\begin{array}{l}\text { - Metabolically stable (not very potent } \\
\text { compared with the affinity of reference } \\
\left.\text { compound Lys-[Lue }{ }^{8}\right] \text { des-Arg }{ }^{9}-\mathrm{BK}\end{array}$ & - Rabbit \\
\hline 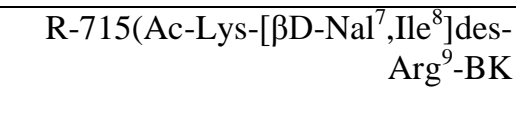 & $\begin{array}{r}\text { - High affinity } \\
\text { - Allergic lung inflammation }\end{array}$ & $\begin{array}{r}\text { - Human and rabbit } \mathrm{B}_{1} \text { receptor } \\
\text { - Mice }\end{array}$ \\
\hline $\begin{array}{r}\text { B9858(Lys-Lys- }\left[\mathrm{Hyp}^{3}, \operatorname{Igl}^{5}, \mathrm{D}-\right. \\
\left.\text { Igl }^{7}, \text { Oic }^{8}\right] \text { des-Arg } \\
\end{array}$ & $\begin{array}{r}\text { - Fairly high selectivity for } \mathrm{B}_{1} \text { receptor } \\
\text { due to Lys } \\
\text { - Metabolically stable residue }\end{array}$ & - Human and rabbit $\mathrm{B}_{1}$ receptor \\
\hline Des-Arg $^{10}$-HOE 140 & $\begin{array}{r}\text { - Residual antagonistic effects on B2 } \\
\text { receptor } \\
\text { - Moderate affinity }\end{array}$ & $\begin{array}{r}\text { - Rabbit jugular vein, guinea pig ileum, } \\
\text { rabbit aorta }\end{array}$ \\
\hline $\begin{array}{r}\text { B9430 (D-Arg-[Hyp }{ }^{3}, \mathrm{Igl}^{5}, \mathrm{D}- \\
\left.\left.\operatorname{Igl}^{7}, \mathrm{Oic}^{8}\right]-\mathrm{BK}\right)\end{array}$ & $\begin{array}{r}\text { - Mixed } \mathrm{B}_{1} \text { and } \mathrm{B}_{2} \text { receptor antagonist } \\
\text { even if desArg }{ }^{9} \text { fragment has substantial } \\
\text { selectivity for } \mathrm{B}_{1} \text { receptor }\end{array}$ & $\begin{array}{r}\text { - Demonstration of compatibility of } \mathrm{B}_{1} \text { and } \\
\mathrm{B}_{2} \text { receptors structure by the accommodation } \\
\text { of a single pharmacophore }\end{array}$ \\
\hline $\begin{array}{r}\text { R-954(Ac-Orn- }\left[\mathrm{Oic}^{2}, \alpha-\mathrm{MePhe}^{5}, \mathrm{D}-\right. \\
\left.\beta \mathrm{Nal}^{7}, \mathrm{Ile}^{8}\right] \text { des-Arg } \\
\end{array}$ & $\begin{array}{r}\text { - Allergic lung inflammation } \\
\text { - Air way allergy }\end{array}$ & $\begin{array}{r}\text { - Mice } \\
\text { - Rat model }\end{array}$ \\
\hline PS020990 & $\begin{array}{r}\text { - Potent and competitive } \mathrm{B}_{1} \text { receptor } \\
\text { antagonist } \\
\text { - High affinity }\end{array}$ & - Human receptor (no in vivo data) \\
\hline $\begin{array}{r}\text {-Compound } 12 \text { (benzodiazepine } \\
\text { based structure) } \\
\text { Benzo-sulfonylamide compounds } \\
\text { - Compound } 12 \\
\text { - Compound } 11 \\
\\
\text { - SSR240612 }\end{array}$ & $\begin{array}{r}\text { - Selective antagonist } \\
\text { - Powerful and selective antagonist } \\
\text { - Hyperalgesia } \\
\text { - Speculative on pain, inflammation and } \\
\text { sepsis } \\
\text { - Inflammation and hyperalgesia }\end{array}$ & $\begin{array}{r}- \text { Rat and dog } \\
\text { - Rabbit aortic preparation, rabbit jugular } \\
\text { vein } \\
\text { - Mice and rat }\end{array}$ \\
\hline
\end{tabular}




\section{Future prospects of $\mathrm{BK}$ related therapy for pathological conditions}

Over the past two decades it has become clear that BK and their receptors are involved in several pathological conditions. As such, the development of $B_{1}$ and $B_{2}$ receptor antagonist will be available in near future in order to provide more selective therapeutic modalities for the treatment of many diseases.

\section{Agonists and antagonists of $B_{1}$ receptor}

Since 1970, many studies were done to develop receptor antagonists. These studies are based on modifying $\mathrm{BK}$ sequences. $\mathrm{B}_{1}$ receptor antagonist was discovered 10 years before $B_{2}$ receptor antagonist. The first family of the compounds responsible for antagonizing $\mathrm{BK}$ and des-Arg ${ }^{9}$-Bk was based on the prototype [leu ${ }^{8}$ ] des-Arg ${ }^{9}-\mathrm{BK}$, it also has specificity for $\mathrm{B}_{1}$ receptor. The table below shows types of $B_{1}$ receptor agonists and antagonists with their pharmacological and clinical applications ${ }^{30}$.

\section{Agonists and antagonists of $B_{2}$ receptor}

$\mathrm{B}_{2}$ receptor was well defined when the first generation of antagonists were produced in 1985 23 . These compounds are based on [D-Phe $\left.{ }^{7}\right]-\mathrm{BK}$ and has agonist/ partial antagonist activity with low potency.

The second generation $\mathrm{B}_{2}$ receptor antagonist has high antagonistic activity compared to the first generation, in which rigidity had been added to the C-terminal region of the peptide by introducing non natural amino acid residue which gives them critical antagonism. In addition, the development of the third generation $B_{2}$ receptor antagonist have evolved toward non peptide drug development programs with oral bioavailability, higher lipophilicity and lower molecular weight. Moreover, some $\mathrm{B}_{2}$ receptor antagonists have been discovered as natural compounds as: martinelline which is a pyrroloquinoline alkaloid isolated from the plant Martinella iquitosensis ${ }^{24}$.

The table below shows types of B2 receptors agonists and antagonists with their pharmacological and clinical application ${ }^{30}$.

\section{BK and human diseases}

Neurological disease: $\mathrm{BK}$ has a significant role in a variety of central nervous system diseases, as $B_{2}$ receptors are widespread within CNS vasculature. This characteristic leads to increased permeability and delivery of chemotherapeutic agents across the blood brain barrier ${ }^{25}$. Also, BK receptors play an important role in the regulation of post traumatic cerebral edema as it can increase blood brain barrier permeability. There are many studies done to show the effect using $B_{2}$ receptor antagonist in the treatment of human traumatic brain injury. First study was done by using the $\mathrm{B}_{2}$ receptor antagonist CP-0127 which was infused in patients with severe focal cerebral contusions presenting 24 to 96 hours after injury for 7 days ${ }^{26}$. Also, it has been reported that the mean peak increase in intracranial pressure as well as mean increase in severity scores was significantly less in treated patients. Moreover, BK receptors have been linked to Alzheimer's disease. Studies show that skin fibroblast derived from patients with familial Alzheimer's disease generated increased amounts of IP3 (inositol phosphate) in response to stimulation with $\mathrm{BK}$. Also, increased $\mathrm{B}_{2}$ receptor expression has been found in Alzheimer's disease fibroblast on their surface.

Airway disease: $B_{2}$ receptor is major $B K$ receptor involved in the airway diseases. It has been reported that inhalation of $\mathrm{B}_{2}$ receptor agonist BK or Lys-BK caused bronchospasm in asthmatic but not in normal subjects, where as weak B1 receptor agonist des $\mathrm{Arg}^{9}-\mathrm{BK}$ failed to cause bronchospasm in either asthmatic or normal subject. In addition, $\mathrm{B}_{2}$ receptor agonist of $\mathrm{BK}$ but not des- $\mathrm{Arg}^{9}-\mathrm{BK}$ caused rhinitis symptoms. The role of $\mathrm{B}_{2}$ receptors in asthma was shown by clinical trials of nebulized icatibant in patients with persistent asthma. It has been demonstrated that after one month of therapy, patients given a higher dose of icatibant had a mean increase of $10 \%$ in forced expiratory volume, which suggest an anti-inflammatory role of $\mathrm{B}_{2}$ receptor antagonist but no effect on bronchodilation was seen. Also, it had been demonstrated that using intranasal insufflation prior to nasal allergen challenge had no effect on the immediate allergic 
nasal response, but it can block histamine hyper responsiveness at 24 hours as well as allergen induced increases in eosinophils, eosinophil cationic protein, kinin and IL8.

\begin{tabular}{|c|c|c|}
\hline Ligands & application & studies \\
\hline $\begin{array}{r}\text { Labradimil ([Hyp }{ }^{3}, \mathrm{Thi}^{5}, 4-\mathrm{MeTyr}^{8} \frac{\text { Agonists }}{\Psi(\mathrm{CH} 2-} \\
\left.\left.\mathrm{NH}) \mathrm{Arg}^{9}\right]-\mathrm{BK}\right)\end{array}$ & $\begin{array}{r}\text { - Vascular permeability (blood brain } \\
\text { barrier): adjuvant to chemotherapy } \\
\text { of brain tumors }\end{array}$ & $\begin{array}{r}\text { - In vivo rodent models } \\
\text { - Human: phase II studies on glioma }\end{array}$ \\
\hline FR190997 & - Hypertension & - Rat \\
\hline 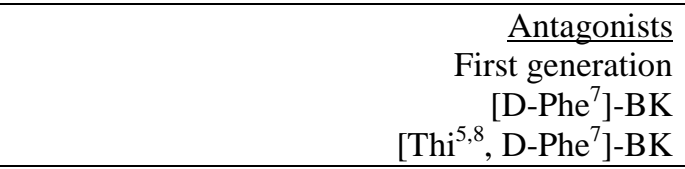 & $\begin{array}{l}\text { - low potency, antagonist/ partial } \\
\text { agonist activity } \\
\text { - Potent antagonist, no agonist } \\
\text { activity }\end{array}$ & $\begin{array}{l}\text { - Rat uterus, guinea pig ileum } \\
\text { - Rat uterus, guinea pig ileum }\end{array}$ \\
\hline $\begin{array}{r}\text { Second generation } \\
\text { HOE } 140 \text { (Icatibant; D-Arg-[Hyp }{ }^{3}, \mathrm{Thi}^{5}, \mathrm{D}- \\
\left.\left.\mathrm{Tic}^{7}, \mathrm{Oic}^{8}\right]-\mathrm{BK}\right)\end{array}$ & $\begin{array}{r}\text { - High affinity, long lasting, } \\
\text { competitive activity } \\
\text { - No residual agonist effect } \\
\text { - Resistance to peptidases } \\
\text { - Acute rhinitis } \\
\text { - Asthma } \\
\text { - Early stage of inflammation } \\
\text { - Persistent inflammatory pain }\end{array}$ & $\begin{array}{r}\text { - Animal model (high affinity for the } \\
\text { human, rabbit and guinea pig } \mathrm{B}_{2} \\
\text { receptor) } \\
\text { - Human, nasal treatment } \\
- \text { Human } \\
- \text { Rat }\end{array}$ \\
\hline $\begin{array}{r}\text { Third generation } \\
\text { Phosphonium family: WIN64 }\end{array}$ & $\begin{array}{r}\text { - In active } \\
\text { - Limited affinity }\end{array}$ & $\begin{array}{r}\text { - On human tissue } \\
\text { - For guinea pig } \mathrm{B}_{2} \text { receptor }\end{array}$ \\
\hline WIN62318 & $\begin{array}{r}\text {-Micromolar binding affinity to } \\
\text { human } \mathrm{B}_{2} \text { receptor }\end{array}$ & $\begin{array}{r}\text { - Identification of the absolute } \\
\text { requirement for } \mathrm{B}_{2} \text { receptor binding } \\
\text { affinity: presence of two positive } \\
\text { charges at a distance about } 10 \mathrm{~A}^{\circ} \\
\text { separated by a lipophilic residue, playing } \\
\text { the role of the } \mathrm{Phe}^{8} \text { side chain in the } \\
\text { native ligand }\end{array}$ \\
\hline $\begin{array}{l}\text { Quinoline and imidazole }[1,2-\alpha] \text { pyridine } \\
\text { family: }\end{array}$ & $\begin{array}{l}\text { - High } B_{2} \text { receptor affinity and } \\
\text { selectivity versus } B_{1} \text { receptor }\end{array}$ & $\begin{array}{r}\text { - Oral activity at doses ranging between } \\
1 \text { and } 30 \mathrm{mg} / \mathrm{kg} \text { in different tests and } \\
\text { species. }\end{array}$ \\
\hline $\begin{array}{l}\text { FR165649, } \\
\text { FR173657, } \\
\text { FR184280 }\end{array}$ & $\begin{array}{r}\text { - Oral activity on hyperalgesia and } \\
\text { inflammation }\end{array}$ & - Rat and mice \\
\hline FR167344 & $\begin{array}{r}\text { - Selective and high potent binding } \\
\text { activity } \\
\text { - bronchoconstriction }\end{array}$ & $\begin{array}{r}\text { - Guinea pig ileum, human A-431 cell } \\
\text { - Guinea pigs (oral activity) designed as } \\
\text { clinical candidate to treat inflammatory } \\
\text { disease }\end{array}$ \\
\hline Compound 38 & - High affinity & - Human $\mathrm{B}_{2}$ receptor \\
\hline $\mathrm{CP} 2522$ & $\begin{array}{r}\text { - High affinity } \\
\text { - Modeled on CP0597 by replacing } \\
\beta \text {-turn conformation of the peptide } \\
\text { by a rigid } 1,4 \text { piperazine ring }\end{array}$ & - Human $\mathrm{B}_{2}$ receptor \\
\hline Substituted 1,4-dihydropyridines & $\begin{array}{r}-\mathrm{B}_{2} \text { receptor antagonist at the } \\
\text { nanomolar range }\end{array}$ & - Human $\mathrm{B}_{2}$ receptor \\
\hline Bradyzide & - Hypertension, inflammation & - Rodent \\
\hline $\begin{array}{l}\text { Natural compound } \\
\text { Pyrroloquinoline alkaloid: Martinelline }\end{array}$ & $\begin{array}{r}\text { - Affinity for both } \mathrm{B}_{1} \text { and } \mathrm{B}_{2} \\
\text { receptors at the micromolar range } \\
\text { but not selective }\end{array}$ & $\begin{array}{l}\text { - Alkaloid isolated from the South } \\
\text { American tropical plant Martinella } \\
\text { iquitosensis }\end{array}$ \\
\hline L-755807 & $\begin{array}{r}\text { - Inhibition of bradykinin binding to } \\
\text { cloned human } B_{2} \text { receptor at } \\
\text { micromolar range }\end{array}$ & $\begin{array}{l}\text { - Complex metabolite isolated from a } \\
\text { culture of the mould Microsphaeropsis sp. } \\
\text { - No future pharmacological data }\end{array}$ \\
\hline
\end{tabular}


On the other hand, the potential role of $B_{1}$ receptor in airway disease has been difficult to establish. It has been shown that the potent $\mathrm{B}_{1}$ receptor agonist lys-des-Arg ${ }^{9}-\mathrm{BK}$ had no acute effect on either the upper or lower airway; however, in rat model of asthma $\mathrm{B}_{1}$ receptor antagonist was found to inhibit allergen induced bronchial hyper responsiveness

This suggests that $B_{1}$ receptors may be involved in allergic airway inflammation. Also, a recent human study reported the expression of $\mathrm{B}_{1}$ receptor in nasal tissue in allergic rhinitis subjects but not in normal ${ }^{27}$. Also, expression of immunoreactive $B_{1}$ receptor was found from patients with interstitial lung disease in transbronchial biopsies, but not in normal lung tissue. In addition, patients taking ACE inhibitors had experienced side effect which is cough. BK has a role in causing cough by acting through stimulation of prostaglandin which is a possible mediator of ACE inhibitor induced cough.

\section{Cancer}

The role of BK receptor in human cancer has been studied, as BK can stimulate growth and increase vascular permeability of tumors. Also, increased generation of $\mathrm{BK}$ has been reported in several types of cancers. Cervical cancer tissue as well as cervical cancer metastatic lesions showed higher expression of both $\mathrm{B}_{1}$ and $\mathrm{B}_{2}$ receptors than normal cervical tissues, in contrast, prostate cancer tissue has been found to express high level of $B_{1}$ receptor compared with normal prostate tissue, as $\mathrm{B}_{1}$ receptor promote cell growth and stimulate ${ }_{28}$ migration as well as invasion in a prostate cell line

Moreover, normal brain tissue expresses $\mathrm{B}_{2}$ receptor on cortical neurons but not on glial cells, unlike brain tissue with astrocytoma which showed $\mathrm{B}_{2}$ receptor on the astrocytic cells as well as variable expression of $\mathrm{B}_{1}$ receptor.

In addition $\mathrm{BK}$ receptor antagonists have been proposed for different cancers specially lung and prostate cancers. The novel BK antagonist CU201 was shown to induce apoptosis and growth inhibition in various lung cancers and other cancer cells as well as its ability to inhibit the growth of prostate cancer in xenograft in nude mice.
In addition, studies had shown that BK antagonists play an important role in cancer. B9870 is most studied BK antagonist dimer as anti cancer agent, at which two molecules of antagonist B9430 are joined at $\mathrm{N}$-terminus. This dimer is selectively cytotoxic at low concentrations for many types of cancer cells, whereas it doesn't damage normal cells. Other BK antagonists having anticancer activity are: B-9870, B-10054 and M-516.

Finally, the discovery that BK antagonists can act synergistically with anticancer drugs open an exciting new avenue for anticancer drug development. Also the fact that aspirin and other NSAIDs inhibit cancer growth may be directly related to recent results with $\mathrm{BK}$ antagonist ${ }^{28}$.

\section{Hypertension}

Is a major risk factor for the development of cardiovascular diseases like coronary heart disease, congestive heart failure, peripheral vascular and renal diseases. It has been shown that the kallikrein kinin system exert a fine control on vascular smooth muscle tone, arterial blood pressure and play a significant cardioprotective effect. Moreover, BK has a vasodilator action on peripheral blood vessels and has potent diuretic and natriuretic effects that regulate sodium excretion from the kidney ${ }^{14}$. The deficiency of KKS may participate in the genesis of hypertension. The involvement of BK in the blood pressure regulation has been confirmed in transgenic mouse models with over expression of human $\mathrm{BK}_{2}$ receptors. This over expression of $\mathrm{BK} \mathrm{B}_{2}$ receptors caused the development of sustained life time hypotension. Also, B1 receptor may be involved in the blood pressure lowering effects under special situation.

It was reported that administration of aprotinin, a tissue kallikrein inhibitor or icatibant, a specific $B_{2}$ receptor antagonist to the transgenic mouse restored their blood pressure to normal level. Also, kininase II (ACE) inhibitors like captopril and enalapril are currently used drugs in the treatment of hypertension ${ }^{29}$. kininase II inhibitors lower blood pressure by blocking the conversion of angiotensin I to angiotensin II and increasing the levels of $\mathrm{BK}^{29}$. Moreover, it has 
been demonstrated that $\mathrm{B} 2$ receptor antagonist FR173657 significantly abolished the hypotensive action of captopril, hence; these drugs should be contraindicated in patients with hypertension. Recently, it has been proposed that tissue kallikrein gene delivery into several hypertensive models results in reduction of blood pressure with the enhancement of capillary growth in spontaneously hypertensive rats, attenuation of cardiac hypertrophy, inhibition of renal damage and fibrosis. These findings may indicate the prospects of kallikrein gene therapy for cardiovascular and renal pathology 29 .

\section{Hereditary Angioedema (HAE)}

Is characterized by hereditary deficiency in $\mathrm{C}_{1}$ inhibitor in contact and complement system. It is associated with increased generation of $B_{2}$ receptor since the activity of kallikrein is largely dependent on contact and complement systems ${ }^{24}$. The $\mathrm{B}_{2}$ receptor antagonist icatibant is currently in the trials for the treatment of attacks of angioedema in HAE patients. Also, aprotinin is a naturally occurring 58 amino acid serpin. It acts by inhibiting the plasma kallikrein which triggers the release of $\mathrm{BK}$ during the contact system activation leading to decreased release of BK during HAE attack. Other drug is DX88 which is a synthetic kallikrein inhibitor based on a recombinant serine protease inhibitor domain. This drug reverses the increase in vascular permeability in $\mathrm{C}_{1}$ INH deficient mice.

\section{Diabetes}

Type 1 diabetes (insulin dependent diabetes mellitus) is an inflammatory autoimmune disease associated with vascular permeability changes leading to many complications. Recently, it was reported that $B K B_{1}$ receptors were found to be up regulated in type 1 diabetes. This effect was recognized when type 1 diabetes was induced in male CD-1 mice by a single injection of streptozotocin, which showed expression of $B_{1}$ receptors in peripheral tissues with various functional consequences when exogenous des$\mathrm{Arg}^{9}-\mathrm{BK}\left(\mathrm{B}_{1}\right.$ receptor agonist) was administered. Interestingly, this type of diabetes in mice is associated with a state of hyperalgesia which suggests some activation of the endogenous kallikrein kinin system. These effects were reversed by $B_{1}$ receptor antagonists like R-954 or R-715 which prevent the progression of insulin dependent diabetes and also reversed hyperalgesia 23.

\section{Undesirable effects of bradykinin}

Many studies reported that BK has many undesirable effects. First of all, BK showed pronounced proinflammatory properties in vivo ${ }^{14}$. These effects are due to activation of cyclooxygenase $\mathrm{COX}-1$ or COX-2 and synergism with $\mathrm{PGI}_{2}$. It has been reported that injecting $\mathrm{BK}$ into skin of experimental animals and human volunteers mimic the cardinal signs of inflammation which are redness, swelling, heat and pain, as well as the accumulation of WBCs. Also, BK causes increased vascular permeability into dorsal skin of rats upon intradermal injection, increased paw swelling upon subcutaneous injection into the hind paw of mice, writhing reactions has been recognized in mice upon intraperitoneal injection and increased angiogenesis as well as granulation upon topical application in mice sponge implants. Other studies have suggested the role of $\mathrm{BK}$ and des- $\mathrm{Arg}^{9}-\mathrm{BK}$ in chronic inflammation as in arthritis. Moreover, thermal and mechanical hyperalgesia have been recognized with $\mathrm{BK} \mathrm{B}_{1}$ receptors. Recently, it has been demonstrated that increasing concentration of $\mathrm{BK}$ enhances rolling and adhesiveness of neutrophils in the mesenteric capillaries of rats.

In addition, the use of ACE inhibitors is associated with various adverse effects, and some of these are associated with the procedures that cause contact activation of $\mathrm{BK}$, as ACE inhibitor is main $\mathrm{BK}$ inactivating metallopeptidase in humans. Angioedema is life threatening side effect which is observed with ACE inhibitors therapy. The pathogenesis of ACE inhibitors induced angioedema is related to $\mathrm{BK}$ and its active metabolite des-Arg ${ }^{9}-\mathrm{BK}$. Also, cough which occurs in 5 to $20 \%$ of patients have been hypothetically attributed to accumulation of endogenous BK. Furthermore, an anaphylactoid or hypersensitivity reaction observed during 
hemodialysis is another acute side effect of ACE inhibitors. Studies have demonstrated an increase in BK concentration in the plasma of patients during acute hypersensitivity reactions.

\section{Conclusion}

$\mathrm{BK}$ is an active endogenous peptide which is involved in a number of pathophysiological conditions such as: pain, fever, GI diseases, rhinitis and shows proinflammatory, in addition to cardioprotective properties. It has been shown that $\mathrm{BK}$ acts through two receptors, $\mathrm{B}_{1}$ and $\mathrm{B}_{2}$ that differ in their mechanism by which they are regulated. The development and use of both B1 and B2 receptor antagonists as potential drug targets has been implicated in several pathophysiological conditions like hypertension, airway diseases, cancer, HAE and diabetes. Recently, it has been reported that there are links between kallikrein kinin system and renin angiotensin system which results from the interactions of their multiple components. Although BK has multiple beneficial effects, some undesirable effects have been documented such as: inflammatory responses, edema, pain and angioedema, which can be overcome by BK antagonists. Finally, a number of other applications are awaiting clear clinical conclusions about the applicability of BK receptor antagonists in inflammatory bowel diseases, asthma, allergy, brain edema and sepsis.

\section{References}

1- Bhoola KD, Figueroa CD, Worthy K. (1992). Bioregulation of kinins: kallikreins, kininogens, and kininases. Pharmacol Rev 44:1-80.

2- Duncan AM, et al. (2000). Kinins in humans. Am J Physiol Regul Integr Comp Physiol 278: R897-904.

3- Wolfrum S, Dendorfer A, Dominiak P. (1999). Identification of kallidin degrading enzymes in the isolated perfused rat heart. Jpn J Pharmacol 79:117-20. doi:10.1254/ijp.79.117
4- Marceau F, et al. (2001). Ligand mediated regulation of kinin receptors in the rabbit. Boil Chem 382: 131-3. doi:10.1515/BC.2001.019

5- Smith CJ, et al. (1996). Reduced gene expression of vascular endothelial NO synthase and cyclooxygenase in heart failure. Cird R 78:58-64.

6- Agata J, et al. (2000). bradykinin $\mathrm{B}_{1}$ receptor mediates inhibition of neointima formation in rat artery after balloon angioplasty. Hypertension 36:364-70.

7- Parenti A, et al. (2001). The bradykinin B1 receptor promotes angiogenesis by up regulation of endogenous FGF-2 in endothelium via the nitric oxide synthase pathway. FASEBJ 15: 1487-9.

8- Shin J, et al. (2002), Bradykinin -12lipooxygenase-VR1 signaling pathway for inflammatory hyperalgesia. Proc Natl Acad Sci USA $\quad 99$ :10150-10155. doi:10.1073/pnas.152002699

9- Stadnicki A, et al. (2005). immunolocalization and expression of kinin $\mathrm{B} 1 \mathrm{R}$ and $\mathrm{B} 2 \mathrm{R}$ in human inflammatory bowel disease. AmJ Physiol Gastrointest Liver Physiol; 289:63616366. doi:10.1152/ajpgi.00369.2004

10- Yusuf Ozturk. (2001), Kinin receptors and their antagonists as novel therapeutic agents. Anadolu University, current pharmaceutical design, 7: 135-161.

11- Uknis AB, et al. (2001). Bradylinin receptor antagonist type 2 attenuate the inflammatory changes in peptidoglycan induced acute arthritis in the Lewis rat. Inflamm Res 50: 149-155. doi:10.1007/s000110050739

12-Samadfam R, et al. (2000). Contribution of $B_{2}$ receptor for bradykinin in arthus reaction induced plasma extravasation in wild type or $\mathrm{B}_{2}$ trasgenic knockout mice. BrJ Pharmacol 129:1732-1738. doi:10.1038/sj.bjp.0703225

13- Walsh DA, Fan TP. (1997). Bradykinin as growth factor. In: The hand book of immunopharmacology. The kinin system. (ed:Farmer SG). Academic Press, USA, P301314.

14- Heitsch H. (2003). The therapeutic potential of bradykinin $\mathrm{B}_{2}$ receptor agonists in the treatment of cardiovascular disease. Expert 
Opin Investig Drugs 12: 759-770. doi:10.1517/13543784.12.5.759

15- Batenburg WW, et al. (2004). Mediators of bradykinin induced vasorelaxation in human coronary microarteries. Hypertension 43: 488492.

doi:10.1161/01.HYP.0000110904.95771.26

16- Cerveuka L, et al. (2001). Angiotensin IIinduced hypertension in bradykinin $B_{2}$ receptor knockout mice. Hypertension 37: 967-973.

17-Imig JD, et al. (2003). The bradykinin $\mathrm{B}_{2}$ receptor is required for full expression renal COX-2 and renin. Peptides 24: 1141-1147. doi:10.1016/j.peptides.2003.07.003

18-Schanstra JP, et al. (2002). In vivo bradykinin $B_{2}$ receptor activation reduces renal fibrosis. Jelin Investig 110: 371-379. doi:10.1172/JCI200215493

19- Bernstein KE. (2002). Two ACEs and a heart. J Nature 471: 799-802. doi:10.1038/417799a

20- Dedio J, et al. (2001). Tissue kallikrein KLK is expressed de novo in endothelial cells and mediates relaxation of human umbilical veins. Biol Chem 382: 1483-1490. doi:10.1515/BC.2001.182

21- Kikkawa Y, et al. (1998). prorenin processing and restricted endopro-teolysis by mouse tissue kallikrein family enzymes (mk1, mk9, mk13, and mk22). Biochim Biophys Acta 1382: 55-64. doi:10.1016/S01674838(97)00144-1

22- AbdAlla S, et al. (2001). Increased AT1 receptor heterodiamers in preeclampsia mediate enhanced angiotensin II responsiveness. J Nat Med 7: 1003-1009. doi:10.1038/nm0901-1003
23- L.M. Fredri Leeb-Lundberg, et al. (2005). International Union of Pharmacology. Classification of the kinin receptor family: from molecular mechanisms to pathophysiological consequences. J Pharmacol Rev 57: 27-77. doi:10.1124/pr.57.1.2

24- Ma D, et al. (2001). First total synthesis of martinellic acid, a naturally occurring bradykinin receptor antagonist, J org Lett. 3: 2189-2191.

25-Borlongan CV and Emerich DF. (2003). Facilitation of drug entry into the CNS via transient permeation of blood brain barrier: laboratory and preliminary clinical evidences from bradykinin receptor agonist, cereport. Brain Res Bull 60: 297-306. doi:10.1016/S0361-9230(03)00043-1

26- Narotam PK, et al. (1998). Traumatic brain contusions: a clinical role for the kinin antagonist CP-0127. J Acta Neuro chir (wien) 140: 793-802.

27- Christiansen SC, et al. (2002). Upregulation of functional kinin $\mathrm{B} 1$ receptors in allergic airway inflammation. J Immunol 169:20542060.

28- Stewart JM. (2003) Bradykinin antagonist as anticancer agents. J Curr Pharm Des 9: 20362042. doi:10.2174/1381612033454171

29-Sharma JN. (2003). Does the kinin system mediate in cardiovascular abnormalities? An overview. J. Clin Pharmacol; 43(11): 11871195. doi:10.1177/0091270003258171

30-Marie Eve Moreau, et al., (2005), the kallikrein- kinin system: current and future pharmacological targets, J Pharmacol Sci 99: 15-16. doi:10.1254/jphs.SRJ05001X 